\title{
Creativity training in organizations: a ready-to-implement concept
}

\author{
Julia Gumula ${ }^{1,2}$ (D) \\ Published online: 3 February 2020 \\ (c) The Author(s) 2020
}

\begin{abstract}
This article_-published in the Journal Gruppe. Interaktion. Organisation._-provides a ready-to-implement creativity training concept with elements of Design Thinking. Although organizations have expressed an increasing interest in creativity training to help their employees become more creative and innovative, recent research indicates effective creativity training is still lacking. The training course described in this report fills this organizational human resource development requirement for practical, effective idea generation techniques. It focuses on increasing the creativity performance during the Design Thinking idea generation phase. The training concept is designed for a one day onsite workshop with up to 40 participants.
\end{abstract}

Keywords Creativity training - Design Thinking $\cdot$ Idea generation techniques $\cdot$ Creativity techniques $\cdot$ Human development $\cdot$ Training concept $\cdot$ Semantic-cognitive jumping

\section{Kreativitätstraining in Organisationen: ein umsetzbares Konzept}

\section{Zusammenfassung}

Dieser Artikel - veröffentlicht in der Zeitschrift Gruppe. Interaktion. Organisation. - bietet ein umsetzungsreifes Konzept für ein Kreativitätstraining mit Elementen des Design Thinking. Obwohl Unternehmen ein zunehmendes Interesse an Kreativitätstrainings bekundet haben, um ihren Mitarbeiter*innen zu helfen, kreativer und innovativer zu werden, zeigen jüngste Untersuchungen, dass ein effektives Kreativitätstraining noch fehlt. Das in diesem Bericht beschriebene Training erfüllt diesen Bedarf der organisatorischen Personalentwicklung an praktischen, effektiven Ideengenerierungstechniken. Es konzentriert sich auf die Steigerung der Kreativitätsleistung während der Ideenfindungsphase im Design Thinking. Das Trainingskonzept ist auf einen eintägigen Workshop vor Ort mit bis zu 40 Teilnehmer*innen ausgelegt.

Schlüsselwörter Kreativitätstraining · Design Thinking · Kreativitätstechniken · Ideengenerierungstechniken · Personalentwicklung · Trainingskonzept · semantisch-kognitives Springen

\section{Introduction}

Innovation is the multi-stage process whereby organizations transform ideas into new/improved products, services or processes, in order to advance, compete and differentiate themselves successfully in their marketplace (Baregheh et al. 2009). Innovation thus requires coming up with ideas that are original as well as effective (Runco and Jaeger 2012) and their implementation. Organizations have an in-

Dr. Julia Gumula

julia.gumula@psych.uni-goettingen.de

1 Universität Göttingen, Göttingen, Germany

2 B. Braun, Melsungen, Germany creasing demand for these different stages (idea generation, idea selection, and implementation) to be effectively facilitated and for their employees to be supported in being creative and innovative. That is why the Design Thinking methodology has become increasingly popular for innovating companies, universities and colleges to facilitate creativity within complex problems (Brückner and Ameln 2016). "Design Thinking is a way of finding human needs and creating new solutions using the tools and mindsets of design practitioners [...] [to] address a wide variety of personal, social, and business challenges in creative new ways" (Kelley and Kelley 2013, p. 24-25). Thus, Design Thinking complements the innovation process with a focus on and a connection to people's needs. Therefore, the Design Thinking method consists of more than the creativity and 
Fig. 1 Creativity Training Schedule (Author's own Sketchnotes)

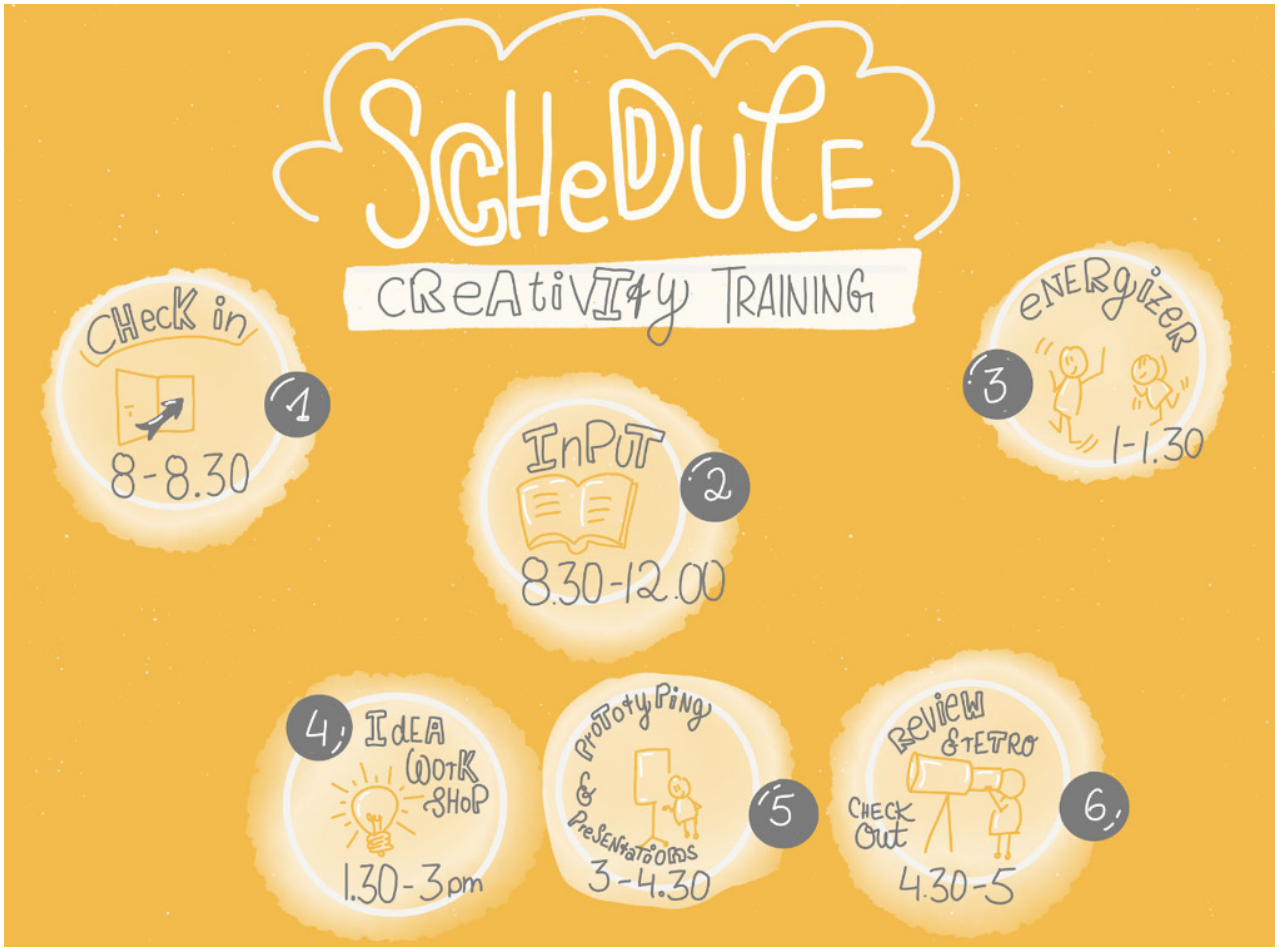

implementation phase and covers at least four stages instead. An innovation may cycle through these stages going back to previous ones-called iterations-before complete (Kelley and Kelley 2013, p. 22). The four stages of Design Thinking cover (1) Inspiration, (2) Synthesis, (3) Ideation and Experimentation, and (4) Implementation.

To come up with original ideas during the ideation stage, there are creativity techniques that both facilitate idea generation and increase the ideas' originality. Van Gundy lists more than 100 such ideation techniques (VanGundy 2005). As even creativity handbooks addressing organizational practice merely list ideation techniques (Eppler et al. 2017; Gray et al. 2010; Nöllke 2015; Seelig 2015; Sherwood 1998) without indicating how the techniques' effectiveness towards the quality of ideas might vary, the question of which techniques to choose during the Design Thinking ideation stage remains unanswered. Because creativity is so essential in the "quest for competitive advantage in today's world of quickly changing technologies and dynamic competitors" (Hender et al. 2002, p. 5), an intensive one-day creativity training was developed addressing organizations' competitive requirement for innovation and creative ideas. The creativity training is designed to empower employees to become innovators and to inspire them by approaching idea generation in ways different to traditional techniques like brainstorming. The techniques are presented here in a detailed manner so that organizations can immediately implement the tools in-house and without additional external facilitators. This paper focuses on ideation techniques which activate knowledge that is semantically unrelated with the ideation task and thus have the potential to outperform traditional ideation techniques like brainstorming or brainwriting.

The paper is structured as follows: the creativity training is described in detail to facilitate immediate application by facilitators. The creativity training comprises a theoretical summary on innovation and a cognitive model describing S-CJ ideation techniques that potentially result in more original but still feasible ideas than brainwriting or brainstorming. The techniques are then explained step-by-step. The last section provides a summary of this paper and implications for practical application.

\section{Description of the creativity training}

The creativity training is designed for up to 40 participants, depending on the space available and takes about a day. It comprises a check in (1), a theoretical input phase (2), an energizer (3), a practical workshop session (4) and presentation of results afterwards (5), ending with a retrospective and feedback as a check out (6). Fig. 1 is intended to give an overview of the training day.

\subsection{Check in}

Participants are welcomed to the training. The schedule and a brief introduction to the topic of innovation are provided 
by displaying a linear innovation process model consisting of four stages:

1. idea generation

2. idea enhancement

3. idea selection

4. prototyping

Then a playful way of introducing each other is suggested: an activating game- "Say something unique"-is played, meant to raise the participants' attention and also to perform an initial ideation as an introductory exercise in which participants learn something interesting about each other.

The whole group is standing. To sit down, people are to reveal an asset about themselves that no one else in the room shares with them, their "unique selling proposition" so to speak. If someone else in the room shares the same asset, participants must continue self-revelations until they hit upon something unique to the group.

\subsection{Theory input for participants: creativity based on spreading activation network theory by Collins and Loftus}

The input session begins with an introduction to innovation processes and creativity techniques. The spreading activation network theory (Collins and Loftus 1975) provides an understanding of how idea generation relies on the socalled spreading activation from concepts closely related to the ideation task to other concepts that are also strongly associated with these first activated concepts. In time, as activation spreads, concepts are activated that have less associative strength with the ideation task. Hence, associative strength decreases, which enables more original ideas to pop up.

Moreover, by way of the spreading activation theory, the principle of the semantic-cognitive jumping (S-CJ)-techniques is explained: $\mathrm{S}-\mathrm{CJ}$ describes the process of activating such concepts that are only weakly related to the ideation task. Hence, when activation spreads from these weakly related concepts to solve the given ideation task, new ideas might evolve that are more original.

\subsubsection{Design-by-Analogy}

Analogical thinking encompasses mapping and transferring information from one domain to another based on similarities between the stimulus and the target (Goldschmidt 2001). For example, when searching for something that is difficult to find, we often refer to the analogy of finding a needle in a haystack.

In the context of creative thinking, analogy - considered the core of cognition (Gentner and Kurtz 2006; Hofstadter
2001) — is also known to be a basis for creativity (Green et al. 2012) and design (Ball and Christensen 2009; Ozkan and Dogan 2013). Analogies are the basic principle of synectics - the term stemming from Greek, meaning "the joining together of different and apparently irrelevant elements" (Gordon 1961).

Analogical reasoning moves from a known example to an abstraction and from an abstraction to a new idea to solve a problem (Casakin 2004; Casakin and Goldschmidt 1999; Ozkan and Dogan 2013). It is a process of establishing correspondence between concepts from different fields of knowledge (Doumas et al. 2008; Gentner and Smith 2012). Regarding creativity, Kao (2014) argues the more distant the analogies the more creative the outcomes (Kao 2014).

Step-by-step-Instruction of the Analogy-technique:

1. Consider precise assets of the issue/problem/task

2. Abstract from the precise issue/problem/task

3. Find analogies with similar problems/solutions/tasks

4. Apply the analogous solution to your issue/problem/task

Example For example, a large automotive manufacturing company was searching for a new design of a machine that would be able to handle large, cubicle metallic items as well as small, delicate workpieces and that would hold on to these very tightly so that working tools could apply high pressure on the items to form them into parts of a car engine. Applying Design-by-Analogy during a Design Thinking workshop, the engineers used the octopus as their biomimetic analogy and designed a machine based on how an octopus would handle his prey.

\subsubsection{Ideal final result}

In the ideal-final-result (IFR) technique, the ideal case is imagined. IFR is a variant of the design-by-analogy technique, because here again, the S-CJ is performed when searching for analogies that have already reached a desirable state. The fictitious ideal case is imagined as a system performing its function without negative side effects (Hipple 2012), granting benefits, doing no harm, costing nothing, occupying no space, and requiring no maintenance (Domb 1997). The technique is also included in TRIZ ${ }^{1}$ - the Russian acronym for theory of inventive problem solving (Altshuller and Shapiro 1956).

\footnotetext{
1 TRIZ is a compilation of inventive principles based on Altshuller's and colleagues' analysis of a large amount of patents. These 40 principles also make use of considering the ideal case and then searching for working principles from other disciplines.
} 
Fig. 2 Example of a solution provided by IFR (Author's own sketchnotes)

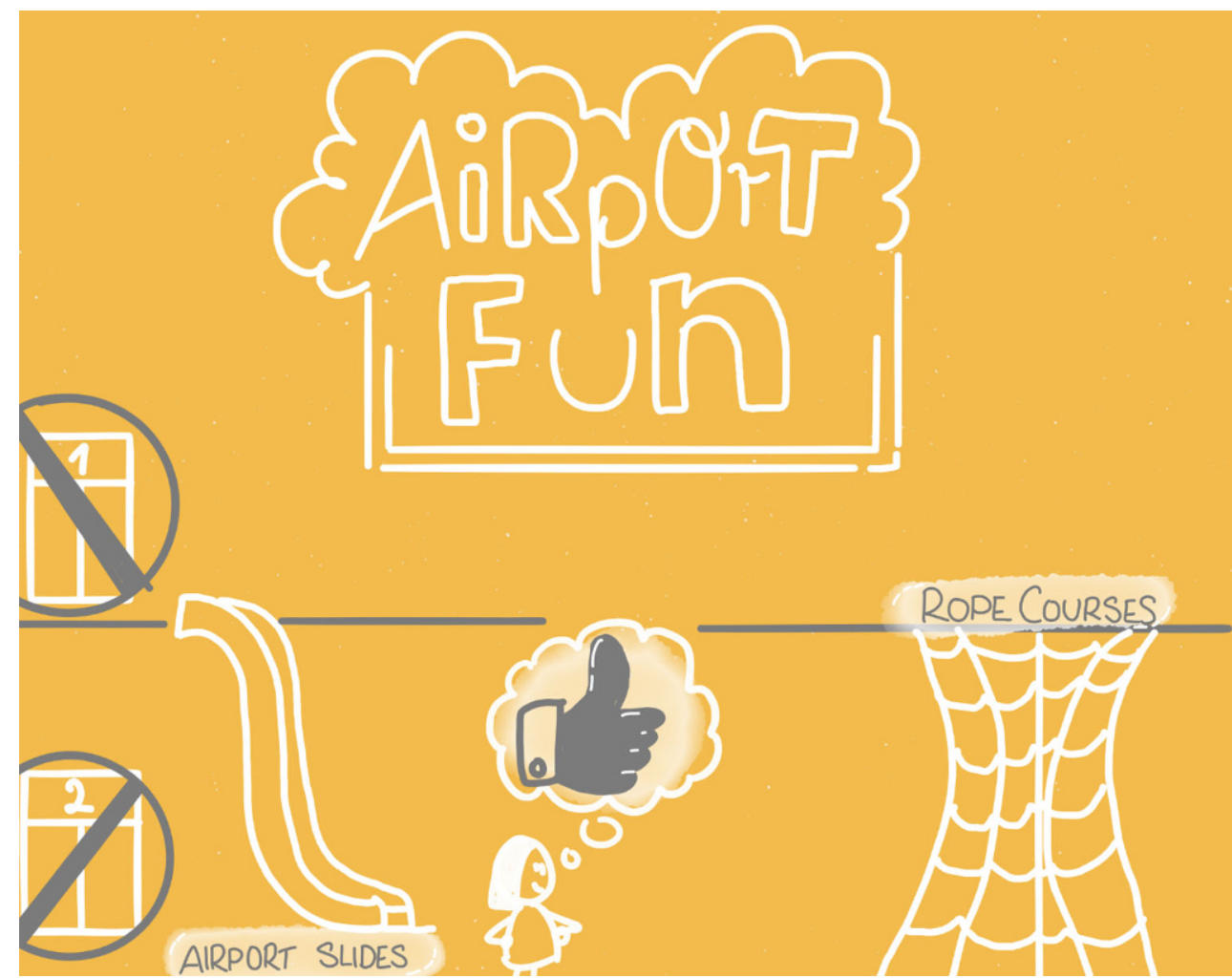

Step-by-step-Instruction of the IFR:

1. Consider the IFR related to your issue/problem/task.

2. Find analogies that have already accomplished the IFR in their domain.

3. Apply the analogous solution to your issue/problem/task.

Example In 2017, the Frankfurt airport was looking for new services for waiting passengers. Applying the IFR technique one would look for situations in which passengers would not have to wait or in which it would not feel as if they were waiting because they would be enjoying their time. What kinds of places or services already offer such fun times? Answers to that question: Time flies by in wellness hotels or while we sleep. People enjoy dancing or riding roller coasters in amusement parks. Using these airport-unrelated stimuli helps form novel solutions: Airports might offer amusement departments with roller coasters, or if only one feature of the amusement park can be applied, the escalators and moving staircases can be complemented by slides or ropes courses (see Fig. 2).

\subsubsection{Adapt-a-Role-technique}

Adapting the customer's role is at the core of Design Thinking, embodying the user, observing and empathizing with him/her is the key element to Design Thinking's success. This is not to be confused with the adapt-a-role technique used in the Design Thinking ideation phase.
Here, the $\mathrm{S}-\mathrm{CJ}$ is accomplished by embodying a special type of person other than ourselves or the customer: a movie star, a comic character, a politician, a soccer player or athlete, etc. That embodying a different person can increase creativity is backed by research: People come up with more creative ideas when they embody a distant other than when embodying a close other or creating ideas for themselves (Polman and Emich 2011). And thinking of how a car would need to be that the Dalai Lama would want to buy is fun.

Step-by-step-Instruction of the Adapt-a-role-technique:

1. Choose any superhero/comic character/celebrity/ scientist/famous athlete

2. Imagine the persona solving your issue/problem/task. Or imagine you would solve the issue/problem/task for the persona-imagining her/him as the customer

3. Solve the issue/problem/task for the persona or by means of embodying the persona

Example How would Arthur Conan Doyle prefer to fly? What kind of seats would he need to write a novel while up in the air? What kind of lighting, sound suppression? How much interaction with other passengers would he want to balance the need between being inspired by human culture and the need to concentrate? These questions enable a new kind of airplane design: retro style, heavy red curtains, intimate illumination, flight attendants in Sherlock Holmes wardrobe etc. 


\subsubsection{Reverse technique}

Assumptions that people have about problems, the statusquo, or constraints hinder innovative thinking and generating novel ideas. Therefore, questioning assumptions is another S-CJ technique. S-CJ is achieved by picturing things or assumptions functioning the other way around: water flows upstream instead of downstream, a bottle is inside the soda, the audience is on the stage while the singers are listening, etc.

Step-by-step-Instruction of the Reverse technique:

1. List all assumptions that you hold true about the issue/ problem/task

2. Reverse each of these assumptions

3 . Use these reversed, sometimes awkward and unrealistic images as a basis for a more realistic solution to the issue/ problem/task

Example To be coherent on the automotive and travelling topic, let us imagine a family planning a vacation and packing their car for the trip. The father does not enjoy packing his car. He starts that packing process two days before the actual trip because he has experienced fitting all the stuff into the trunk a highly challenging task. Using the reverse technique one would say: the car is not packed by the father, the car is packing itself. Based on a tracking system linked to online shopping websites, the smart car "knows" both the amount and the size of all the family's suitcases. A smartphone app_-using virtual reality-tells the father exactly where to put each suitcase so that the trunk space is ideally used. In fact, it is so much fun, that the children love helping their dad with that endeavor.

\subsubsection{Provocation}

Another technique also based on the reversal of assumptions is the provocation technique (DeBono 1970) and is known to lead to higher levels of creativity (Herrmann and Felfe 2014). Again, all assumptions are listed and then each assumption is questioned by introducing a counter statement. This counter statement is marked by a "PO"-identifying it as the provocation.

Step-by-step-Instruction of the Provocation Technique:

1. The ideation facilitator introduces counterintuitive statements marked with a PO

2. Use these awkward and unrealistic images as a basis for a solution to the issue/problem/task

Example Another mechanical engineering task related to the automotive sector: usually, to improve the precision of a metal cutting machine, engineers had assumed that in order to cut precise holes into workpieces, either the work piece or the tool must be kept in place. One must stay in place while the other one moves. Provocation/PO: both move. Ideas generated from it: the two pieces move towards each other flexibly like robots.

\subsubsection{Exaggeration}

Exaggeration requires overdoing one of the assumptions about a problem or an ideation task and then imagining the state in which a product or service would be that has these overdone features. Exaggeration is commonly used in advertising.

Step-by-step-Instruction of Exaggeration technique:

1. Consider one or more assets about the issue/problem/task

2. Take the asset to the outmost extreme-imagine the asset to be, for instance, ridiculously strong or extremely weak

3. From this exaggerated asset, consider consequences that can be useful and apply them to your issue/problem/task

Example When it comes to exaggeration in advertisement, the Mercedes Benz slogan "The best or nothing" is an example to be quoted.

\subsection{Energizer: game "Grandma, Lion, Samurai"}

Since the first part of the creativity training is theory-laden, before entering the practical ideation phase, participants are asked to join in another activating game comprising some physical activity. Oppezzo and Schwartz (2014) have shown that physical activity (walking on a treadmill or outside) prior to ideation has a great effect on creativity (Oppezzo and Schwartz 2014).

"Grandma, Lion, and Samurai" is played like "Rock, Paper, Scissors" but instead of only making hand gestures, people make a characteristic noise while embodying and mimicking a grandmother, a lion, or a samurai. The grandmother points her finger and scolds the samurai, the samurai raises his blade and beheads the lion, the lion's roar scares the grandmother.

Two groups are formed, each selects their champion who then opposes the other team's champion. Champions are selected in round robin fashion so that each group member has her/his turn.

\subsection{Workshop session-put theory into practice}

\subsubsection{Ideation phase}

Usually, scholars testing the effectiveness of different ideation techniques rely either on standardized tests such as the Alternative Uses Task (AUT) in which participants come up with unusual uses for everyday objects (Storm and Patel 2014; Sun et al. 2016) or have participants think of ways to improve their university (Baruah and Paulus 2008; 
Goldenberg et al. 2013; Paulus et al. 2013). Other scholars asked subjects to think of advantages and disadvantages of an additional thumb (Dugosh et al. 2000; Dunnette et al. 1963; Kohn et al. 2011; Paulus and Dzindolet 2008). Since the creativity training was not conducted in the laboratory but was designed as applied research, the ideation task was not supposed to benefit only scientific rigor by way of replicating previous methods but was meant to benefit private and public-sector organizations to improve their competitive edge by training their employees in effective creativity and innovation thinking.

Therefore, in the first field test setting of application held with male and female journeymen, two ideation challenges from this specific professional domain were presented to participants:

1. come up with advertisement for their own (future) business

2. identify real-world problems that they themselves or their clients might face and creatively develop solutions to these problems.

To ideate on advertising for their businesses (1), attributes and unique assets of their services, products, and their future companies are collected in a plenary session. Afterwards, participants work individually. They choose which ideation technique they want to apply and create advertisement ideas. Later they stroll through the room, read and comment on their colleagues' ideas and exchange feedback to further advance each other's solutions.

The problem identification and solving-task (2) has two stages-finding a problem, followed by solving the problem. The problem identification is done in a plenary session to help participants get started on their task by assisting them in gathering as many current and potential customer problems as possible.

In the problem-solving stage they individually list assumptions and attributes on one problem that they have decided to work on and then choose which technique they want to apply. Depending on that choice, they either reverse the listed assumptions or come up with analogies that also face the same problem. Afterwards, they again stroll through the room, comment on other people's ideas, combine their innovative solutions and exchange feedback.

\subsubsection{Selection phase}

Although each idea may function as an advertisement or may solve the problem task, selecting the highest quality ideas is essential. Instead of selecting ideas based on personal preference, the creativity training provides selection criteria to guide towards the best ideas. Are the advertising ideas feasible, attention grabbing, cost less than 200 Euros and are unique? Are the problem solving ideas feasible, effective and unique? From all ideas that pass these two individual selection processes, the participants may choose their favorite idea each to create prototypes.

\subsection{Prototyping and final presentation}

Participants enhance the selected ideas and develop them into prototypes. There are various forms of prototypes such as sketches, 3D-models, storyboards, mock-ups, etc. Through prototyping, the ideas and the resources they require become tangible and people gain a mutual understanding of what they want the idea to look like in terms of which functions are mandatory. Since in the creativity training field test there were only limited resources available and standardization between each test was crucial, participants had to stick to pen and paper to create posters. In reality, pen and paper prototypes do not suffices. Therefore organizations are called upon to provide various materials and media technology so that idea prototyping can utilize the rich supply of creativity material available today: tape, dough, Lego bricks, pipe cleaners, duct tape etc.

Towards the end of the training course, participants present their prototypes to an audience of simulated trade experts and customers who in fact are fellow participants and the facilitator. The audience in turn provides feedback on the pitched solutions. If the feedback is rather negative, new ways to improve the idea are to be found, serving another iteration.

In applied settings, it is advisable to have real customers engage with the prototype and collect feedback from them. If possible, pitching the idea to the management board might assure early sponsorship and supervisor support, raising the possibility of the idea being implemented.

\subsection{Check out-review and retrospective}

Following the final step of the creativity training - the above described presentation of prototyped ideas-participants are asked to provide feedback on the course (review) and the interaction between participants (retrospective) so that the creativity training itself can continuously be improved to meet customer requirements.

The creativity training ends by thanking the participants for their attendance and feedback.

\section{Discussion}

A detailed description of the training course was presented allowing for its immediate application in organizational practice. A few weak points of the creativity training should be reported: for example, when addressing practice, com- 
plex models like the spreading activation theory (Collins and Loftus 1975) might need more detailed explanation.

Interestingly, the knowledge provided in the creativity training seems to be not very novel. Designers have long been applying design-by-analogy, also reflected in the fact, that for example the analogy based techniques called Synectics have been developed in the 1960s (Gordon 1961); SCAMPER $^{2}$ in the 1970 (Eberle 1972). What is new, however, is the combination of the cognitive model (spreading activation network theory) and the ideation techniques in the light of this new creativity training.

Although innovation covers the creation and implementation of ideas (Baregheh et al. 2009), the implementation phase cannot be covered by a one-day long workshop as has been proposed here. Only theoretical knowledge on the implementation can be provided, leaving the realizing of ideas obtained in the trainees' and organizations' responsibility. Future training concepts might focus more on implementation skill and controlling.

Life in the 21st century is characterized by uncertainties (Kashani-Vahid et al. 2017). Social, economic and technological changes make it almost impossible to predict the required skills in the future world (Beghetto 2010). However, scholars agree that being able to deal with ill-defined problems is and will continue to be mandatory. This ability calls for creative thinking skills on both the personal and organizational level (Kashani-Vahid et al. 2017).

Creativity trainings are proven to enhance participants' creativity outcome (Scott et al. 2004) and since even small changes in the originality of ideas increase customer's willingness to pay a profitable price, creativity trainings rise in value for organizations (Dahl and Moreau 2002).

Since highly original ideas are the explicit desired outcome here, their unusualness and novelty could cause them to be even harder to implement due to lack of existing organizational underpinnings. For sounder organizational practice regarding innovation and maintaining an organization's competitive edge, the provision of in-house mentoring programs and counselling for innovating teams is suggested. That way, ideas which might win the race to market are not abandoned due to lacking support. Innovating teams' need for management support and encouragement is likely to be positively correlated with the originality of their ideas, causing guidance and mentoring to become an essential or-

\footnotetext{
${ }^{2}$ SCAMPER is a checklist of different creativity techniques. S stands for substitute, $\mathrm{C}$ for combine, A for adapt, $\mathrm{M}$ for modify, $\mathrm{P}$ for put to another use, $\mathrm{E}$ for eliminate and $\mathrm{R}$ for rearrange. Eberle calls it a model for creative imagination development (Eberle 1972). In retrospective the techniques suggested in the creativity training have overlap with the $\mathrm{P}$ - put to another use principle. However, reverse technique, provocation, and adapt a role-technique are not part of the SCAMPER checklist.
}

ganizational practice for surviving the uncertainty of the modern competitive climate.

Funding This study was funded by The Hans-Böckler-Foundation, Foundation Of The German Trade Associations, Düsseldorf, Germany.

Funding Open Access funding provided by Projekt DEAL.

Open Access This article is licensed under a Creative Commons Attribution 4.0 International License, which permits use, sharing, adaptation, distribution and reproduction in any medium or format, as long as you give appropriate credit to the original author(s) and the source, provide a link to the Creative Commons licence, and indicate if changes were made. The images or other third party material in this article are included in the article's Creative Commons licence, unless indicated otherwise in a credit line to the material. If material is not included in the article's Creative Commons licence and your intended use is not permitted by statutory regulation or exceeds the permitted use, you will need to obtain permission directly from the copyright holder. To view a copy of this licence, visit http://creativecommons.org/licenses/by/4. $0 /$.

\section{References}

Altshuller, G. S., \& Shapiro, R. V. (1956). About a technology of creativity. Questions of Psychology, 6, 37-49.

Ball, L. J., \& Christensen, B. T. (2009). Analogical reasoning and mental simulation in design: Two strategies linked to uncertainty resolution. Design Studies, 30(2), 169-186. https://doi.org/10.1016/ j.destud.2008.12.005.

Baregheh, A., Rowley, J., \& Sambrook, S. (2009). Towards a Multidisciplinary Definition of Innovation. Management Decision, 47(8), 1323-1339. https://doi.org/10.1108/00251740910984578.

Baruah, J., \& Paulus, P. B. (2008). Effects of Training on Idea Generation in Groups. Small Group Research, 39(5), 523-541. https:// doi.org/10.1177/1046496408320049.

Beghetto, R. A. (2010). Creativity in the classroom. In J.C. Kaufman \& R. J. Sternberg (Eds.), The Cambridge handbook of creativity (pp. 447-463). Cambridge: Cambridge University Press.

Brückner, F., \& von Ameln, F. (2016). Agilität. Gruppe Interaktion Organisation, 47, 383. https://doi.org/10.1007/s11612-016-0334-6.

Casakin, H. (2004). Visual Analogy as a Cognitive Strategy in the Design Process. Expert versus Novice Performance. Journal of Design Research. https://doi.org/10.1504/JDR.2004.009846.

Casakin, H., \& Goldschmidt, G. (1999). Expertise and the use of visual analogy: Implications for design education. Design Studies, 20, $153-175$.

Collins, A.M., \& Loftus, E.F. (1975). A spreading-activation theory of semantic processing. Psychological Review, 82(6), 407-428. https://doi.org/10.1037/0033-295X.82.6.407.

Dahl, D. W., \& Moreau, P. (2002). The Influence and Value of Analogical Thinking during New Product Ideation. Journal of Marketing Research, 39(1), 47-60. https://doi.org/10.1509/jmkr.39.1.47. 18930.

DeBono, E. (1970). Lateral thinking: creativity step by step. New York: Harper \& Row.

Domb, E. (1997). The Ideal Final Result: Tutorial. The TRIZ Journal. https://triz-journal.com/ideal-final-result-tutorial/

Doumas, L. A. A., Hummel, J. E., \& Sandhofer, C. M. (2008). A theory of the discovery and predication of relational concepts. Psychological Review, 115(1), 1-43. https://doi.org/10.1037/0033-295X. 115.1.1.

Dugosh, K. L., Paulus, P. B., Roland, E. J., \& Yang, H.-C. (2000). Cognitive stimulation in brainstorming. Journal of Personality and Social Psychology, 79(5), 722-735. https://doi.org/10.1037/00223514.79.5.722. 
Dunnette, M.D., Campbell, J., \& Jaastad, K. (1963). The effect of group participation on brainstorming effectiveness for 2 industrial samples. Journal of Applied Psychology, 47(1), 30-37. https://doi. org/10.1037/h0049218.

Eberle, R.F. (1972). Developing Imagination Through Scamper. The Journal of Creative Behavior, 6(3), 199-203. https://doi.org/10. 1002/j.2162-6057.1972.tb00929.x.

Eppler, M.J., Hoffmann, F., \& Pfister, R.A. (2017). Creability: Gemeinsam kreativ - innovative Methoden für die Ideenentwicklung in Teams. Stuttgart: Schäffer-Poeschel.

Gentner, D., \& Kurtz, K. J. (2006). Relations, Objects, and the Composition of Analogies. Cognitive science, 30(4), 609-642. https:// doi.org/10.1207/s15516709 $\operatorname{cog} 0000 \_60$.

Gentner, D., \& Smith, L. (2012). Analogical Reasoning. In Encyclopedia of Human Behavior (pp. 130-136). Amsterdam: Elsevier. https://doi.org/10.1016/B978-0-12-375000-6.00022-7.

Goldenberg, O., Larson, J.R., \& Wiley, J. (2013). Goal Instructions, Response Format, and Idea Generation in Groups. Small Group Research, 44(3), 227-256. https://doi.org/10.1177/10464964 13486701.

Goldschmidt, G. (2001). Visual analogy: A strategy for design reasoning and learning. Design Knowing and Learning: Cognition in Design Education. https://doi.org/10.1016/B978-0080438689/50009-7.

Gordon, W. J. J. (1961). Synectics: the development of creative capacity. New York: Harper \& Row.

Gray, D., Brown, S., \& Macanufo, J. (2010). Gamestorming: a playbook for innovators, rulebreakers, and changemakers. Sebastopol: O'Reilly.

Green, A. E., Kraemer, D. J. M., Fugelsang, J. A., Gray, J. R., \& Dunbar, K. N. (2012). Neural correlates of creativity in analogical reasoning. Journal of Experimental Psychology. Learning, Memory, and Cognition, 38(2), 264-272. https://doi.org/10.1037/a0025764.

Hender, J.M., Dean, D.L., Rodgers, T.L., \& Nunamaker Jr, J.F. (2002). An Examination of the Impact of Stimuli Type and GSS Structure on Creativity: Brainstorming Versus Non-Brainstorming Techniques in a GSS Environment. Journal of Management Information Systems, 18(4), 59-85. https://doi.org/10.1080/ 07421222.2002 .11045705$.

Herrmann, D., \& Felfe, J. (2014). Effects of Leadership Style, Creativity Technique and Personal Initiative on Employee Creativity. British Journal of Management, 25(2), 209-227. https://doi.org/ 10.1111/j.1467-8551.2012.00849.x.

Hipple, J. (2012). The Ideal Result. New York: Springer.

Hofstadter, D. R. (2001). Epilogue: analogy as the core of cognition. In D. Gentner, K. J. Holyoak \& B. N. Kokinov (Eds.), The analogical mind: Perspectives from cognitive science (pp. 499-538). Cambridge, London: MIT Press.

Kao, C.-Y. (2014). Exploring the relationships between analogical, analytical, and creative thinking. Thinking Skills and Creativity, 13, 80-88. https://doi.org/10.1016/j.tsc.2014.03.006.

Kashani-Vahid, L., Afrooz, G., Shokoohi-Yekta, M., Kharrazi, K., \& Ghobari, B. (2017). Can a creative interpersonal problem solving program improve creative thinking in gifted elementary students? Thinking Skills and Creativity, 24, 175-185. https://doi. org/10.1016/j.tsc.2017.02.011.

Kelley, T., \& Kelley, D. (2013). Creative Confidence: Unleashing the Creative Potential Within Us All. New York: Crown Business.

Kohn, N. W., Paulus, P. B., \& Korde, R. M. (2011). Conceptual Combinations and Subsequent Creativity. Creativity Research Journal, 23(3), 203-210. https://doi.org/10.1080/10400419.2011.595659.

Nöllke, M. (2015). Kreativitätstechniken. Haufe TaschenGuide. Freiburg: Haufe-Lexware.
Oppezzo, M., \& Schwartz, D.L. (2014). Give Your Ideas Some Legs: The Positive Effect of Walking on Creative Thinking. Journal of Experimental Psychology. Learning, Memory, and Cognition, 40(4), 1142-1152. https://doi.org/10.1037/a0036577.

Ozkan, O., \& Dogan, F. (2013). Cognitive strategies of analogical reasoning in design: Differences between expert and novice designers. Design Studies, 34(2), 161-192. https://doi.org/10.1016/ j.destud.2012.11.006.

Paulus, P. B., \& Dzindolet, M. (2008). Social influence, creativity and innovation. Social Influence, 3(4), 228-247. https://doi.org/10. 1080/15534510802341082.

Paulus, P.B., Kohn, N.W., Arditti, L.E., \& Korde, R. M. (2013). Understanding the Group Size Effect in Electronic Brainstorming. Small Group Research, 44(3), 332-352. https://doi.org/10.1177/ 1046496413479674.

Polman, E., \& Emich, K.J. (2011). Decisions for Others Are More Creative Than Decisions for the Self. Personality and Social Psychology Bulletin, 37(4), 492-501. https://doi.org/10.1177/ 0146167211398362.

Runco, M. A., \& Jaeger, G. J. (2012). The Standard Definition of Creativity. Creativity Research Journal, 24(1), 92-96. https://doi.org/ 10.1080/10400419.2012.650092.

Scott, G., Leritz, L. E., Mumford, M. D. (2004). The Effectiveness of Creativity Training: A Quantitative Review. Creativity Research Journal, 16(4):361-388

Seelig, T. (2015). Insight Out: Get Ideas Out of Your Head and Into the World. New York: HarperOne.

Sherwood, D. (1998). Unlock Your Mind: Practical Guide to Deliberate and Systematic Innovation. Vermont: Gower.

Storm, B.C., \& Patel, T. N. (2014). Forgetting as a consequence and enabler of creative thinking. Journal of Experimental Psychology. Learning, Memory, and Cognition, 40(6), 1594-1609. https://doi. org/10.1037/xlm0000006.

Sun, J., Chen, Q., Zhang, Q., Li, Y., Li, H., Wei, D., \& Qiu, J. (2016). Training your brain to be more creative: brain functional and structural changes induced by divergent thinking training. Human Brain Mapping, 37(10), 3375-3387. https://doi.org/10.1002/hbm. 23246.

VanGundy, A.B. (2005). 101 Activities for Teaching Creativity and Problem Solving. San Francisco: Pfeiffer.

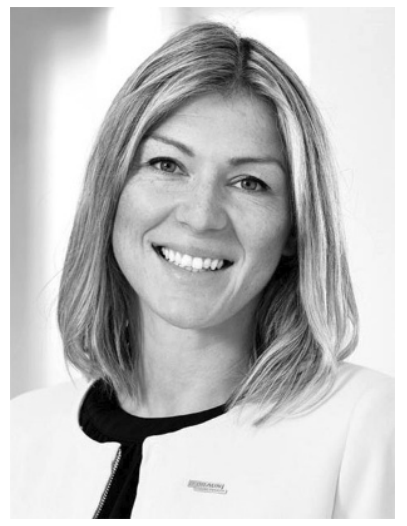

Julia Gumula Als Teil einer Inhouse Organisationsentwicklungseinheit von B. Braun unterstützt Julia Gumula ihre Kolleg*innen dabei, selbstorganisiert zusammenzuarbeiten und kreativ zu sein. Vor ihrem Einstieg beim Melsunger Medizintechnikkonzern hat Julia an der Georg-August-Universität Göttingen zur Effektivität verschiedener Kreativitätstechniken im Design Thinking promoviert. Studiert hat sie Cultural Engineering an der Otto-von-Guericke Universität Magdeburg - ein interdisziplinärer Studiengang mit Fokus auf

Corporate Culture Change. Sie lebt mit ihren drei Kindern und ihrem Mann bei Kassel und spielt in ihrer Freizeit (das bisschen, was noch übrig bleibt) Handball. 